\title{
Genetic Variability, Heritability and Association of Quantitative Traits in Maize (Zea mays L) Genotypes: Review Paper
}

Mamud Aman*

Ethiopian Institute of Agricultural Research, Hawassa maize research, P.O.Box: 1793, Hawassa, Ethiopia

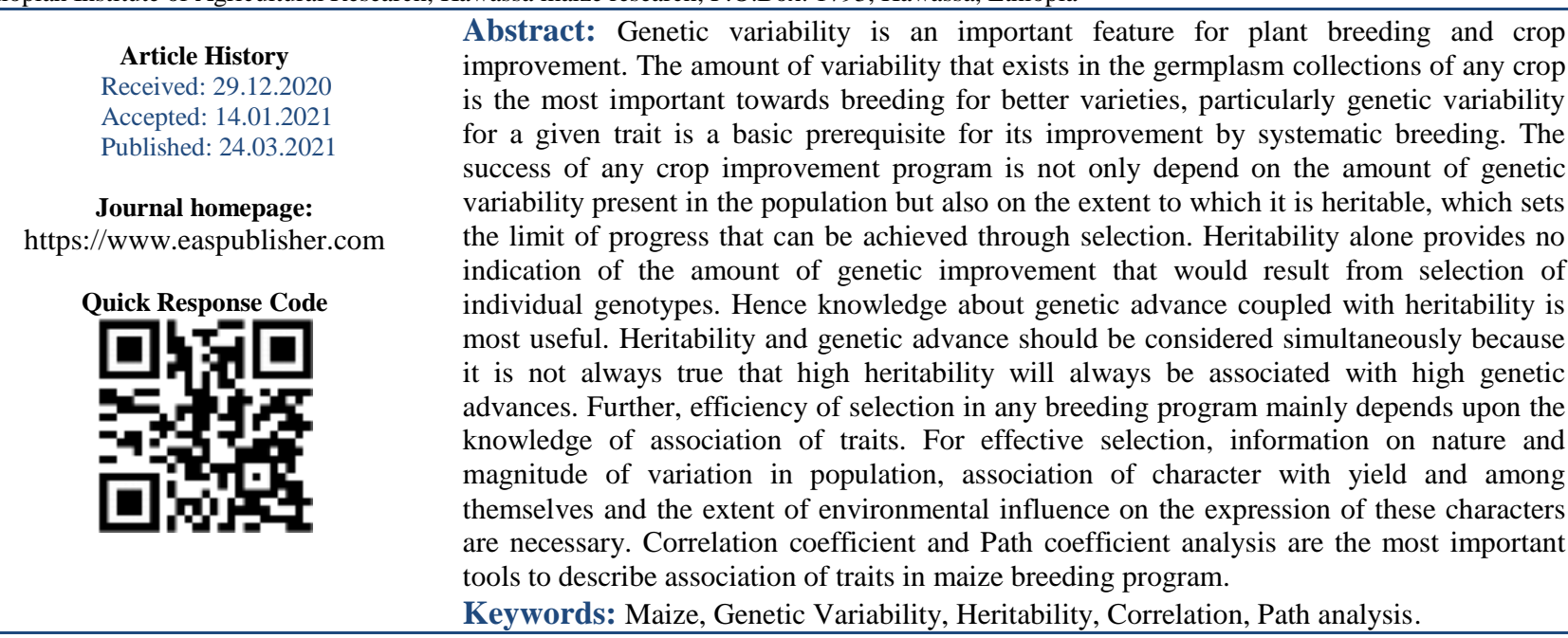

Copyright (C) 2021 The Author(s): This is an open-access article distributed under the terms of the Creative Commons Attribution 4.0 International License (CC BY-NC 4.0) which permits unrestricted use, distribution, and reproduction in any medium for non-commercial use provided the original author and source are credited.

\section{INTRODUCTION}

Maize (Zea mays L.) is the world's most widely grown cereal crop. It is one of the most important food crops worldwide, serving as staple food, livestock feed, and industrial raw material [1]. Among cereal crops, maize has the highest average yield per ha and remains third after wheat and rice in total area and production in the world. It is one of the most important staple food crops in sub-Saharan Africa (SSA), predominantly produced and consumed directly by the smallholder farmers [2]. Maize grows in most parts of the world over a wide range of environmental conditions, with altitudinal ranges of 0 to 3000 meters above sea level [3].

In Ethiopia, maize is one of the most important cereal crops grown in almost all parts of the country with high production in Oromia, Amhara, Southern Nation, Nationality and people and Tigray regions mainly for food security [4]. Among cereals, maize ranks second to tef (Eragrostis tef) in area coverage with 2.13 million hectares, but first in productivity and grown by more than 10.5 million smallholder households, more commonly than any other crop in the country [5]. Maize is everything for the Ethiopian maize farmers. Three fourth of the maize produced is consumed at the household level by the small-scale producers themselves [6]. The grain is consumed in different forms of food; the Stover is used as feed, fuel and construction material. Besides, it serves as a major source of income and means of employment for 10 million of farming and business communities. Due to its widespread significance in the country, maize is one of the strategic field crops targeted to ensure food security in Ethiopia. Despite its importance and large area under maize, the average yield of maize in Ethiopia (3.94 t ha 1 ) is below the world average (5.6 t ha 1) [7].

The low productivity of maize is attributed to many production challenges including drought, declining of soil fertility, disease and insect pests such as Maize lethal necrosis (MLN), Maize Streak Virus (MSV), Turcicum Leaf blight (TLB), Gray leaf spot (GLS), southern leaf rust, blight, stalk borers, and the parasitic weed Striga hermonthica [8]. Besides many factors, unavailability of sufficient number of suitable maize varieties are also one of the possible reasons responsible for such yield gap. Efforts are, therefore, required to be made to develop hybrids with high yield potential to increase production of maize.

Development of high yielding maize varieties is the most fundamental goal of any maize breeder to 
increase yield. Grain yield is the collective product of inherited and environmental factors. Genetic variability in maize genotypes plays a vital role in grain yield variation [9]. Maize production could be increased through development of improved genotypes capable of producing enhanced yield under different agro-climatic conditions. Genetic variability among maize genotypes can be estimated based on qualitative and quantitative traits. Based on characters selection among genotypes was carried out.

Study of yield contributing components in respect of their genetic mechanism is very important for improvement of crop production especially grain yield. The mean values, genotypic and phenotypic variances, heritability, and the correlation coefficients of agronomic traits are some of the key parameters which determine the efficiency of a breeding program. Information regarding inter-relationships between quantitatively inherited traits and their direct and indirect effects on grain yield is of great importance for success in selections to be conducted in breeding programs [10].The analysis of correlation coefficient is the one among numerous methods that can be used for this purpose but, it cannot provide reasons of association. Besides, knowing the correlations between the traits is also of great importance for success in selection and analysis of correlation coefficient is the most widely used among numerous methods [11]. For effective selection, information on nature and magnitude of variation in population, association of character with yield and among themselves and the extent of environmental influence on the expression of these characters are necessary [11].

\section{OBJectives}

- To review genetic variability, heritability and association between different quantitative traits of maize genotypes

- To review and provide information on interrelationships of yield with other important yield components.

\section{LITERATURE REVIEW \\ Origin and Distribution of Maize}

Maize (Zea mays L., $2 \mathrm{n}=2 \mathrm{x}=20$ ) is annual crop belonging to the grass family Poaceae and tribe Maydeae, While maize comes in five phenotypes (sweet, pop, floury, dent, and flint) originated 5,000 to 10,000 years ago [12]. Maize originated in Central America and was introduced to West Africa in the early 1500 s by the Portuguese traders [3]. Similar to other crop species, maize arose from a wild, weedy species native to the area. Several theories have been formulated to account for the origin of maize, but the exact relationship between Teosinte, Tripsacum, and early pod maize found in archaeological ruins has not yet been fully resolved [13]. Generally, two locations have been suggested as possible centers of origin for maize, namely, the highlands of Peru, Ecuador, and Bolivia, and the region of southern Mexico and Central America.

The Portuguese introduced maize to Southeast-Asia from the America in the $16^{\text {th }}$ century. Maize then followed a very complicated pattern of introduction to different continents, including the North and South Americas, Europe and Africa [14]. Most of such introductions happened several centuries ago, and maize landraces with better adaptability have been selected by the farmers to the new environments, leading to several new derivatives in the process. The crop expanded in its range from the lowlands to the highlands, and has become the number one crop in the continent in terms of cultivated area and total grain production [8]. The crop is rapidly spreading all over the globe because it is relatively easy to cultivate and most productive where rainfall and irrigation is adequate. More recently, several varieties have been released and utilized different countries in Africa, including Ethiopia [15, 16].

\section{Importance of Maize}

Maize is the major food crop grown all over the world [17]. Maize is one of the world's three major cereal crops and its share of the total world grain production is substantial and significant. Maize is used in more ways than any other cereal. Though grain is the most important component for which maize is grown, all parts of the plant such as leaves, stalk, tassel, husk and cob are all employed for different purposes. It is one of the most productive species of food plants and utilized directly as a source of food for human consumption, animal feed or feed for livestock and currently as fuel for vehicles [18]. In the developed world, maize is mostly used for animal feed (70\%) and only a small percentage (5\%) is consumed by humans, while in developing countries maize is generally used as food $(62 \%)$ of maize as food and $(34 \%)$ is used as feed. The remaining proportion is used for varied industrial uses and as seed. In developing countries consumption of maize is high throughout most of the region, reflecting its role as the primary food staple [19].

\section{Maize Germplasm Diversity}

Maize is one of the domesticated crop species with the highest level of genetic diversity. Genetic diversities are important components of crop improvement programs $[20,21]$. The molecular diversity of maize is approximately three to tenfold higher than that of other domesticated grass crops [22]. Several factors are suggested as reasons for this diversity in maize, viz., (1) variability of environments, culture, production system and the type of consumption of maize [23]; (2) the high level of out-crossing in maize favors continuous gene exchange between 
neighboring plants, and in some cases, with their wild relatives; (3) chromosomal duplications in maize are extensive, providing new mutational opportunities for creating greater phenotypic variability [24].

The great diversity of environments and conditions have created the basis for the development of maize varieties well adapted to harsh conditions of soil and climate as well as to biotic stresses. There is a close correlation among community culture, production system and the type of consumption of maize, with the diversification and variation of maize [23]. There is a growing trend in developing countries to adopt improved maize varieties, primarily to meet market demand. The narrowing of genetic diversity in modern maize varieties emphasizes the importance of conserving genetic traits for future plant breeding. CIMMYT (International Maize and Wheat Improvement Centre) has taken the lead in preserving maize germplasm. It has the world's largest collection of maize accessions, with over 17,000 lines [25].

\section{Genetic Variability in Maize}

Genetic variability is the pre requisite for any crop improvement program. Genetic variability, which is a heritable difference among cultivars, is required at an appreciable level within a population to facilitate and sustain an effective long term plant breeding program. Progress from selection has been reported to be directly related to the magnitude of genetic variance in the population. Improvement in any trait depends solely on the amount of variability present in the base material for that trait. Therefore, variability is a key for crop improvement [26].

The Study of variability and genetic advance in the germplasm will help to ascertain the real potential of the genotype [27]. Accordingly, study of genetic parameters like genotypic coefficient of variation, phenotypic coefficient of variation, heritability and genetic advance as per cent of mean provides a clear cut idea about the extent of variability present in a plant population and a relative measure of efficiency of selection of genotypes based on phenotype in a highly variable population([28]. Genetic knowledge of germplasm diversity among local populations has a significant impact on the improvement of plant and is a valuable source of useful traits but also a bank of highly adapted genotypes. Germplasm, which is a prerequisite for any breeding program serves as a valuable source material as it provides scope for building of genetic variability.

A number of studies in maize have been conducted to illuminate the nature of association between yield and its components which identified traits like ear length, ear diameter, kernels per row, ears per plant, 100-seed weight and rows per ear as potential selection criteria in breeding programs aimed at high yield [29]. Other investigators, [30] reported that, high genetic variability in grain yield per plant and ear height of different germplasm. Similarly, [31] also observed high genetic variability in maize for yield per plant and ear height. According to [32] who studied on genetic variability of maize, the phenotypic coefficients of variations (PCV) were higher than the genotypic coefficients of variations $(\mathrm{GCV})$ for all the traits studied. Thousand seed weight had the highest GCV and the trait days to silk had the highest PCV. The highest genetic gain was obtained for plant height and the lowest genetic gain was recorded for the number of leaves per plant. This suggests broader genetic base for number of leaves per plant among the genotypes studied.

In another finding [33], reported high PCV and GCV values for grain yield per plant and ear height in maize. Moderate PCV values of ear girth, ear length, 100 grain weight and number of grain rows per cob were reported by [33]. Other researchers, [34] have reported significant genetic differences in plant and ear height in maize genotypes. Similarly $[35,36]$, observed considerable genotypic variability among various maize genotypes for different traits. [37] also reported significant genetic differences for morphological traits of maize genotypes. Hussain, M. A and Hassan, Z. A. [38] reported high genetic variability among maize hybrids for all the traits.

\section{Heritability}

Heritability is a parameter which is widely used in the establishment of breeding programs and formation of selection indexes [39]. The estimates of genotypic coefficient of variation (GCV) reflect the total amount of genotypic variability which is transmitted from parents to the progeny is reflected by heritability. The success of any crop improvement program is not only depend on the amount of genetic variability present in the population but also on the extent to which it is heritable, which sets the limit of progress that can be achieved through selection [40]. Theoretically, heritability can range from one (1) where all variation is due to genetic, to zero (0) where all the variation results from the environment. Actual heritability value will fall somewhere between these extreme values. It is difficult to determine the amount or types of genetic variability if phenotypic expressions are strongly influenced by the environment or less heritable [41, 42].

Heritability assumes that individuals more closely related are more likely to resemble one another than distant ones. Estimate of heritability assists breeders to allocate resources necessary to effectively select for desired traits and to achieve maximum genetic gain with little time and resources [39]. There are different ways to calculate heritability. It may be estimated as broad-sense or narrow-sense, on single plant, individual plot or mean of entry. Heritability 
values that give the proportion of the total phenotypic variation that is due to all genetic factors are known as broad sense heritability. Broad-sense heritability plays a predictive role in breeding, expressing the reliability of phenotype as a guide to its breeding value. In broad sense heritability, high value indicate that, the character is least influenced by environmental effects.

The most important function of heritability in genetic studies of quantitative characters is its predictive role to indicate the reliability of phenotypic value as a guide to breeding value [39]. Characters with high heritability can easily be fixed with simple selection resulting in quick progress. High heritability is associated with additive gene effect which if easily fixable whereas low heritability is due to dominance and epistasis which is not fixable easily. There is a direct relationship between heritability and response to selection, which is referred to as genetic progress [39].

Several researchers have reported high heritability estimates for grain yield and yield related traits. [34] Observed high heritability for plant height ear height, tassel length, tassel branch, number of rows per ear and grain yield. Similarly, high and moderate heritability were reported for plant height by [43, 44] respectively. High heritability of both these traits indicates a wide range of variation and genetic differences among the populations. [38] Observed high broad sense heritability estimates for different traits such as days to tasseling, days to silking, plant height ear height, number of rows per ear, number of kernels per row and thousand seed weight. According to [45] heritability was greater than $80 \%$ for all characters studied. Another investigators, [46, 47] have also reported high heritability for different yield controlling traits in maize.

However, it has been accentuated that heritability alone has no practical importance without genetic advance. High genetic advance coupled with high heritability estimates offers the most effective condition for selection [27]. The utility of heritability therefore increases when it is used to calculate genetic advance, which indicates the degree of gain in a character obtained under a particular selection pressure. Since high heritability does not always indicate a high genetic gain, heritability is recommended to be considered in association with genetic advance to predict the effect of selecting superior crop varieties. Therefore, genetic advance is yet another important selection parameter that aids breeder in a selection program [48].

\section{Genetic Advance}

Heritability alone does not indicate the amount of genetic improvement that would result from selection of individual genotypes. Hence knowledge about genetic advance coupled with heritability is most useful. Character exhibiting high heritability may not necessarily give high genetic advance [48]. Showed high heritability should be accompanied by high genetic advance to arrive at more reliable conclusion. Genetic advances measure the expected genetic progress that would result from the best performing genotypes for the trait being evaluated [49]. Heritability and Genetic advance should be considered simultaneously because it is not always true that high heritability will always be associated with high genetic advances [48].

Improvement in the performance of selected plant over the original population can be termed as genetic advance. The ultimate goal of the plant breeder is to have higher genetic advance for the material selected since it is an indicator for the genetic improvement made in a population under selection. The genetic gain can be expected for a particular trait through selection. The genetic gain that can be expected for a particular trait through selection is the product of heritability, phenotypic standard deviation and selection differential [50]. The heritability estimated either "Broad sense" or Narrow sense" are useful only for the population or genotypes under consideration as these estimates vary with the set of genotypes considered. The estimates of genetic advance help in understanding the type of gene action involved in the expression of various polygenic traits [50].

Generally, high genetic advance coupled with high heritability estimates offers the most suitable condition for selection. It also indicates the presence of additive genes in the trait and further suggests reliable crop improvement through selection of such traits. Estimates of heritability with genetic advance are more reliable and meaningful than individual consideration of the parameters [48].

\section{Association of Quantitative Traits in Maize}

Study of variability and genetic advance in the germplasm will help to ascertain the real potential of the genotype [27]. Further, efficiency of selection in any breeding program mainly depends upon the knowledge of association of traits [51]. Phenotypic correlation indicates the extent of the relation between two traits, while genotype correlation provides an estimate of inherent association between the genes controlling two traits. For effective selection, information on nature and magnitude of variation in population, association of character with yield and among themselves and the extent of environmental influence on the expression of these characters are necessary [11]. Both Correlation coefficient and Path coefficient analysis are the most important tools to describe association of traits in maize breeding program. 


\section{Correlation coefficient}

Correlation coefficient is a statistical measure which is used to find the degree and direction of association between two characters in plant breeding experiments. A correlation coefficient tells that whether there is relationship between two variables and whether the relationship is positive or negative and how strong or weak the relationship [52]. The intensity of correlation coefficient is represented as $r$ and ranges from -1 to +1 . It is independent of unit of measurement. If $r=-1$, it indicates the relation between two characters in opposite direction, i.e., the high value of one character is associated with low value of other character. If $r=+1$, then complete perfect association between the two characters varying in the same direction is predicted. If $r=0$, there is no correlation between the variables and the variances are independent of each other. In plant breeding simple correlation coefficient is measured to find out mutual relationship between two plant characters and to determine the component characters, on which selection can be done for genetic improvement in yield. It is of three types, i.e., phenotypic, genotypic and environmental [53].

The association between two traits that can be directly observed is the correlation of phenotypic values or phenotypic correlations (rp). Phenotypic correlations measure the extent to which the two observed traits are linearly related. It is determined from measurements of the two traits in a number of individuals of the populations. Genotypic correlation ( $\mathrm{rg}$ ) is the associations of breeding values (i.e., additive genetic variance) of the two traits. Genetic correlations measure the extent to which the same genes or closely linked genes cause co-variation (simultaneous variations) in two different traits. The correlations of environmental deviations together with non-additive genetic deviations (i.e., dominance and epistatic genetic deviations) are referred to as environmental correlations (re) [54].

Several workers have estimated correlation coefficient among yield and other quantitative traits in maize [55]. Found that yield components that had the highest correlation with yield in maize were the number of ears per plant, followed by plant height and ear height while ear diameter and ear length having very small correlation with yield [56]. Also reported positive and significant correlation of yield with ear length, thousand-kernel weight, ear diameter, number of kernel rows per ear, number of kernels per row, plant height and number of ears per plant. They also noted significant negative correlation between yield and days to silking and maturity.

Dagne, 2008 [57] found positive and highly significant phenotypic correlation between grain yield and plant height, ear height, ear diameter, ear length, number of kernel rows per ear and thousand kernel weights at Bako under optimum and low nitrogen conditions. He also reported negative and highly significant phenotypic correlation between grain yield and days to silking and days to anthesis at Bako under both conditions. Correlation of the association of grain yield with other traits was estimated by genotypic and phenotypic coefficients, plant height was correlated positively and significantly with all the traits at genotypic level. Grain yield per plant was correlated positively and significantly with plant height at genotypic level and positively and non-significantly at phenotypic level.

Immanuel and Nagarajan [58] reported positively and significantly associated grain yield with plant height, ear height, ear length, ear girth, number of kernels per row, number of rows per ear and starch content, hundred seed weight and carotene content [59]. Found that, positive and highly significant correlations between grain yield and ear height, ear length, and number of kernels per row, while it had a negative and highly significant correlation with ear aspect. He also found positive and highly significant correlations of Ear height with thousand kernel weight and grain yield [45]. Also reported positively correlated of days to anthesis and silking, plant height and number of leaf per plant with grain yield [60]. Found positive correlation between grain yield and plant height, number of rows per ear, number of kernel per row and 100- kernel weight and emphasized the role of these traits in selection of high grain yield in maize. Components of variance revealed a wide range of variability for all the traits. Variances arising due to differences among genotypes were highly significant for all the traits [61]. This result showed that simple regression coefficient is not enough for selection of traits which affect grain yield [62]. Investigated highly significant and positive correlations of ear length, ear diameter and number of kernels per row with grain yield. Similar findings were reported by $[63,64]$ for positive correlation of grain yield with ear length and [47] for ear diameter and number of kernels per ear [65]. Reported highly significant genotypic and phenotypic correlations of number of ears harvested and field weight with grain yield.

\section{Path Coefficient Analysis}

Path-coefficient analysis is originally developed by [66]. It is the most valuable tool to establish the exact correlation in terms of cause and effect. The relative importance of direct and indirect effects of measured traits on grain yield will be determined by path analysis. It is simple standardized partial regression coefficient which splits the correlation coefficient into direct and indirect effects of the yield components on yield estimated as suggested by [66] and elucidated by [69]. For example, if we need to formulate selection indices for genetic improvement of yield, the cause and effect of the trait is very essential and can be done by path analysis [54]. 
Phenotypic and genotypic correlation coefficients could further be analyzed by path coefficient analysis, which involves the partitioning of the correlation coefficients into direct and indirect effects through alternate traits or path ways. Such analysis leads to identification of important component traits useful in indirect selection for higher yield. Estimation of simple correlation coefficient helps the breeders to determine the association between traits, but they do not provide the real picture of direct and indirect influence of each trait associated with the other trait. This weakness of correlation analysis can therefore be overcome by path coefficient analysis [67].

Studies of correlation and path coefficient analysis would be very important to design appropriate breeding strategies for improvement in yield through selection and to have better understanding of the relationship among yield related traits [69]. Yield, being a complex trait, has been observed to be associated with a number of component traits. Grain yield in maize, specifically, is the result of a number of complex morphological and physiological traits. For full understanding of the complex relationships between grain yield and other traits, the computation of direct and indirect effects of these traits on grain yield is essential. Path coefficient analysis is used to standardize the data, determine simple correlations between independent factors, and to regress all the independent factor separately in order to obtain the direct effects in the form of partial regression coefficients (path coefficients) [68].

Partitioning the correlation coefficients into components of direct and indirect effects and assessment of the relative importance of each causal factor affecting yield is possible through the pathcoefficient analysis. When the correlation coefficient between a causal factor and the effect (e.g. grain yield) is almost equal to its direct effects, correlation explains the true relationship and a direct selection through this trait (causal factor) will be effective. In path coefficient analysis, grain yield is considered as dependent variable and the remaining traits are considered as independent variables [54]. If the correlation coefficient is positive, but the direct effect is negative or negligible, the indirect effects seem to be cause of correlation and in such situations; the indirect causal factors are to be considered simultaneously for selection [54]. On the other hand [54], suggested that, under the circumstances of negative correlation coefficient but positive and high direct effect, a restricted simultaneous selection model is to be followed. That is, restrictions are to be imposed to nullify the undesirable indirect effects in order to make use of the direct effects.

Several studies have been done by different researchers with different findings on partitioning the correlation coefficients into components of direct and indirect effects for grain yield and other agronomic traits. [70], determined the interrelationship between grain yield and its components from eighteen maize lines or hybrids, using genotypic correlation and path coefficient analysis and found that, grain yield correlated with number of grains per ear, 1000 grain weight, number of kernel per ear and ear height. [71], reported positively and significantly associated grain yield with plant and ear height, ear diameter, number of grains per ear, number of grains per row and 1000 grain weight. [72] also concluded that days to $50 \%$ silking had positive and significant association with each other and grain yield per plant under drought condition. After getting information from the results of regression and correlation analysis, the path coefficient analysis was done to determine direct and indirect effects of traits on grain yield [72].

Other researchers, [58] reported positive direct effects of days to silking, plant height, ear height, ear length, ear girth, number of kernels per row, number of rows per ear and starch content, hundred seed weight and carotene content with grain yield. He also reported positive indirect effect of plant height on grain yield via number of rows per cob and crude protein and negative indirect effect of plant height on grain yield via ear height, days to tasseling, days to silking, ear length, ear girth, number of grains per row, number of grains per ear, hundred seed weight, starch and carotene [63], also found that ear length had high positive direct effect on grain yield, which support the present result. On the other hand, days to $50 \%$ tasseling, days to $50 \%$ silking and ear height had negative direct effect on grain yield.

\section{CONCLUSION}

Maize (Zea mays L.) is the most important crop in terms of production and distribution in Ethiopia. Among cereals, maize ranks second to tef in area coverage with 2.13 million hectares, but first in productivity $(3.94 \mathrm{t} / \mathrm{h})$ and grown by more than 10.5 million smallholder households, more commonly than any other crop in the country. It is one of the most important staple food crops in sub-Saharan Africa (SSA), predominantly produced and consumed directly by the smallholder farmers. Maize grows in most parts of the world over a wide range of environmental conditions, with altitudinal ranges of 0 to 3000 meters above sea level.

Genetic variability is the important feature for plant breeding and crop improvement. The amount of variability that exists in the germplasm collections of any crop is of at most importance towards breeding for better varieties, particularly genetic variability for a given trait is a basic prerequisite for its improvement by systematic breeding. The success of any crop improvement 
program is not only depend on the amount of genetic variability present in the population but also on the extent to which it is heritable, which sets the limit of progress that can be achieved through selection.

Heritability alone does not indicate the amount of genetic improvement that would result from selection of individual genotypes. Hence knowledge about genetic advance coupled with heritability is most useful. Heritability and genetic advance should be considered simultaneously because it is not always true that high heritability will always be associated with high genetic advances. In plant breeding, simple correlation coefficient is measured to find out mutual relationship between two plant characters and to determine the component characters, on which selection can be done. A correlation coefficient tells that whether there is relationship between two variables and whether the relationship is positive or negative and how strong or weak the relationship.

Generally, high genetic variability and heritability coupled with high genetic advance offers the most suitable condition for selection. It also indicates the presence of additive genes in the trait and further suggests reliable crop improvement through selection of such traits. Estimates of heritability with genetic advance are more reliable and meaningful than individual consideration of the parameters.

\section{REFERENCE}

1. Troyer, A. F. (2006). Adaptedness and heterosis in corn and mule hybrids. Crop Science, 46(2): pp.528-543.

2. Shiferaw B, Prasanna BM, Hellin J, Bänziger M. (2011). Crops that feed the world. Past successes and future challenges to the role played by maize in global food security. Food Security 3(3):307327.

3. Dowswell, C. R., R.L. Paliwal and R.P. Cantrell. (1996). Maize in third world. West View Press, Colorado, USA

4. CSA. (2013). Agricultural Sample survey: report on area and production of major crops (private peasant holdings, Meher season). Statistical Bulletin, (1): Addis Ababa.

5. CSA (Central Statistics Agency). (2018). Agricultural sample survey 2017/2018 (2010 E. C.) volume I report on area and production of major crops (Private Peasant Holdings, Meher Season). Stat. Bull. 586. Addis Ababa

6. CSA. (2017). Central Statistical Agency Agricultural Sample Survey, Report on area and production of major crops. Www.csa.gov.et. Accessed 20 December 2017.

7. FAOSTAT. (2017). Statistical databases and datasets of the Food and Agriculture Organization of the United Nations. http://www.fao.org/faostat/en/\#data/QC.
(Accessed 6 July 2019).

8. FAOSTAT. (2015). Statistical databases and datasets of the Food and Agriculture Organization of the United Nations.

9. Tahir M, Tanveer A, Ali A, Abbas M, Wasaya A. (2008). Comparative yield performance of different maize (Zea mays L.) hybrids under local conditions of Faisalabad-Pakistan. Pak. J. Life Soc. Sci., 6(2), 118- 120.

10. Khan K, Sher H, Iqbal M and Al-Qurainy F. (2011). Development and release of indigenous maize hybrids to enhance maize yield in KhyberPakhtoonkhua province of Pakistan. Afri. J. Agric. Res., 6(16): 3789 -3792.

11. Yağdı K. (2009). Path coefficient analysis of some yield components in durum wheat (Triticum durum Desf). Pak. J. Bot., 41(2): 745-751

12. Paliwal, R.L. and M.E. Smith. (2002). Tropical maize: Innovative approaches for sustainable productivity and production increases. pp. 43-73. Food Products Press, an imprint of Haworth Press, Binghamton, New York.

13. Poehlman, J.M. 1987. Breeding field crops. AVI publishing company, Inc, Westport

14. Dubreuil P, Warburton ML, Chastanet M, Hoisington D and Charcosset A. (2006). More on the introduction of temperate maize into Europe: large-scale bulk SSR genotyping and new historical elements. Maydica 51281-291.

15. Langyintuo, A.S., Mwangi, W., Diallo, A.O., MacRobert, J., Dixon, J. and Bänziger, M. (2010). Challenges of the maize seed industry in eastern and southern Africa: A compelling case for private-public intervention to promote growth. Food Policy, 35(4): pp.323-331.

16. Worku M, Legesse W, Berhanu T, Girma D, Girum A, Wende A, Tolera K, Gezahegn B, Dagne W, Solomon A . (2012). Status and future direction of maize research and production in Ethiopia. In M. Worku, Twumasi-Afriyie, S., Wolde, L., Tadesse, B., Demise G., Bogale, G., Wegary, D. and Prasanna, B.M. (Ed.), Meeting the Challenges of Global Climate Change and Food Security through Innovative Maize Research, Addis Ababa pp. 17.

17. FAO (Food and agriculture organization of the United Nations).( 2011). Crop Prospects and Food Situation

18. FAOSTAT. (2010). Statistical databases and datasets of the Food and Agriculture Organization of the United Nations.

19. Felix, M., M. Stephen, M. Murenga A. Leah. (2010). Maize Production and Improvement in Sub Saharan Africa. ABSF 2: 16-17.

20. Mohammadi, S.A., and B.M. Prasanna. (2003). Analysis of genetic diversity in crop plants salient statistical tools and considerations. Crop Science 43:1235-1248.

21. Kitti, B., S. Peerasak, S. Pramote and J. Choosak. (2012). Genetic distance and heterotic 
pattern among single cross hybrids within waxy maize (Zea mays L.). SABRAO Journal of Breeding and Genetics 44:382-397.

22. Buckler, E.S., J.M. Thorns berry, and S. Kresovich. (2001). Molecular diversity, structure and domestication of grasses. Genetics Research 77:213-218.

23. Aguirre, G., M.R. Bellon, and M. Smale. (1998). A regional analysis of maize biological diversity in South-Eastern Guanajuato, Mexico. CIMMYT Economics Working Paper 98-06. CIMMYT, Mexico.

24. Helentjaris, T., D. Weber, and S. Wright. (1998). Identification of genomic locations of duplicate nucleotide sequences in maize by analysis of restriction fragment length polymorphisms. Genetics 118:353-363.

25. CIMMYT. (2000). CIMMYT in 1999-2000: Science and Sustenance. CIMMYT, Mexico D.F., Mexico.

26. Welsh, J. (1981). Fundamental of plant breeding and genetics. Jhon Welicy and sons, New York.

27. Larik AS, Malik SI, Kakar AA, Naz MA. (2000).Assessment of heritability and genetic advance for yield and yield components in Gossypium hirsutum L. Scientific Khyber 13: 3944.

28. Bocanski, J., Sreckov, Z., \& Nastasic, A. (2009). Genetic and phenotypic relationship between grain yield and components of grain yield of maize (Zea mays L.). Genetika, 41(2), 145-154.

29. Reizai. (2004). Estimate of heterosis and combining ability in maize (Zea mays L.)Using diallel crossing method. In Proceedings of the $17^{\text {th }}$, General congress; Genetic variation for plant breeding, 8-11 September, Vienna 2004. 395-398.

30. Mahto RN, Ganguli DK, and Yadava MS. (2002). Evaluation of inbred lines and their F1 crosses of maize. J. Res., Birsa Agric. Univ., 14 (1): 45-49.

31. Rather, A. G., Bhatt, M. A and Zargar, M. A. (2003). Genetic variation in maize (Zea mays L.) population in high altitude temperate conditions in Kashmir. Indian Journal of Agricultural Sciences. 79(3): 179-180.

32. Mansir Yusuf. (2010) .Genetic variability and correlation in single cross hybrids of quality protein maize (Zea mays L.) volume 10. No.2.

33. Singh, P. K., Jha, P. B. and P., Kumar. (2003). Path coefficient for green fodder yield and grain yield in maize (Zea mays L.).J. Appl. Biol., 13(1/2): 29-32.

34. Ishaq Muhammad, Hidayatur Rahman, Ghulam Hassan, Muhammad Iqbal, Ibni Amin Khalil, Sabaz Ali Khan, Sheraz Ahmad Khan, Rafiullah and Jamal Hussain. (2015). Genetic Potential, Variability and Heritability of Various Morphological and Yield Traits among Maize Synthetics. Electronic Journal of Biology, Vol.11 (4): 187-191
35. Hallauer, A. R. and J. H. Schos. (1973). Change in quantitative traits associated with inbreeding in synthetic variety of maize. Crop Sci. 13 (3): 327330 .

36. Grzesiak, S. (2001). Genotypic variation between maize (Zea mays L.) single-cross hybrids in response to drought stress. Acta Physiologic Plantarium. 23 (4): 443-456.

37. Ihsan H. I., H. Khalil, H. Rehman and M. Iqbal. (2005). Genetic variability for morphological traits among exotic maize hybrids. Sarhad J. Agric. 21 (4): 599-602.

38. Hussain, M. A, Hassan, Z. A. (2014). Genetic variability, heritability and correlation studied for yield and yield components in maize hybrids. Sarhad Journal of Agriculture, 30(4): 472-478.

39. Falconer DS and Mackay TFC.(1996). Introduction to quantitative genetics. 4th ed. Benjamin Cummings, England, pp. 245-247.

40. Sumathi P, Nirmala Kumari A and Mohan Raj K. (2005). Genetic variability and traits interrelationship studies in industrially utilized oilrich CIMM YT lines of maize (Zea mays L). Madras Agric. J. 92 (10-12): 612-617.

41. Basazen. (2006). Genetic Variability and trait associations in some triticale genotypes at Kulumsa and Assasa, Arsi. An MSc thesis presented to the school of graduate studies of Haramaya University. 57p.

42. Yasien, M. (2000). Genetic behavior and relative importance of some yield components in relation to grain yield in maize (Zea mays $L$.). Ann. Agric. Sci. Moshtohor, 38: 689-700.

43. Ojo DK, Omikunle OA, Oduwaye OA. (2006). Heritability character correlation and path coefficient analysis among six inbred-lines of maize. World Journal of Agricultural Sciences. 2: 352-358.

44. Mahmood Z, Malik SR, Akhtar R, Rafique T. (2004). Heritability and genetic advance estimates from maize genotypes in Shishi Lusht, a valley of Karakuram. International Journal of Agriculture and Biology. 6: 790-795.

45. D.J. Ogunniyan, S.A. Olakojo. (2015). Genetic variation, heritability, genetic advance and agronomic character association of yellow elite inbred lines of maize (Zea mays L.). Nigerian Journal of Genetics, 28 (2014) 24-28.

46. Akbar M, Shakoor M S, Hussain A and Sarwar M. (2008). Evaluation of maize 3-way crosses through genetic variability, broad-sense heritability, characters association and path analysis. J. Agric. Res., 46(1): 39-45. International Journal of Plant Research, 2(5): 138-145

47. Rafiq C.M, Rafique M, Hussain A and Altaf M. (2010). Studies on heritability, correlation and path analysis in maize (Zea mays L.). Agric. Res., 48(1): $35-38$. 
48. Johnson, H.W., Robinson, H.F. and Comstock, R.E. (1955). Genotypic and phenotypic correlations and their implications in selection of soybean. Agron. J., 47: 477-483.

49. Allard, R.W. (1999). Principle of plant breeding. John Wiley and son. New York.

50. Kassaye Negash. (2006). Studies on genetic divergence in common Bean (phaseolus Vulgaris 1.) Introductions of Ethiopia. An MSc thesis presented to the school of graduate studies of Addis Ababa university.110p

51. Uddin, M. Amiruzzaman, S. A. Bagum, M. A. Hakim and M. R. Ali. (2008). Combining Ability and Heterosis in Maize (Zea mays L.)

52. Bello OB, Abdulmaliq SY, Afolabi MS, Ige SA. (2010). Correlation and path coefficient analysis of yield and agronomic characters among openpollinated maize varieties and their F1 hybrids in diallel cross. African Journal of Biotechnology, 9(18): 2633-2639.

53. Arya K, Dijee Bastian, Lekharani C, KM Abdul Khader. 2013. A Practical Manual on Principles of Plant Breeding.

54. Singh, R.K. and B.D. Chaudhary. (1977). Biometrical methods in quantitative genetic analysis. Kalyani Publishers, New DehliLudhiane. 318p.

55. Robinson, H. F., R.E. Comstock and P.H. Harvey. (1955). Estimates of heritability and the degree of dominance in maize. Agron. J. 41: 353-359.

56. Singh, R. and L.B. Chawdhari. (1972). Relation of certain agronomic characters of maize hybrids with yield. Plant Breeding Abstract. 42: 590.

57. Dagne. (2008). Combining ability analysis for traits of agronomic importance in maize (Zea mays L.) inbred lines with different levels of resistance to grey leaf spot (Cercospora zeaemaydis).

58. Immanuel and Nagarajan. (2011). Interrelationship and Path-coefficient Studies for Qualitative Traits, Grain Yield and other Yield Attributes among Maize (Zea mays L.). International Journal of Plant Breeding and Genetics 5 (3): 209-223, 2011.

59. Demissew. (2014). Genetic diversity and combining ability of selected quality protein maize ( QPM) inbred lines adapted to the highland agroecology of Ethiopia By A thesis submitted in partial fulfilment of the requirements for the degree of Doctor of Philosophy ( $\mathrm{PhD}$ ) in Plant Breeding.

60. Katta, Y. S. (2002). Correlation and path coefficient analysis for grain yield and its components in some maize hybrids (Zea mays L.). J.Agric. Sci., Mansoura Univ., 27(6): 3697-3705.
61. Mohan, Y.C. D, K.Sigh and N.V.Rao. (2002). Path coefficient analysis for oil and grain yield in maize (Zea mays L.) genotypes. National J.plant improvement, 4(1): 75-76.

62. Begum S., A. Ahmed, S. H. Omy M. M. Rohman and M. Amiruzzaman. (2016). Genetic Variability, Character Association and Path Analysis in Maize (Zea mays L.). Bangladesh J. Agril. Res. 41(1): 173-182.

63. Batool, Z., K. Danial, P. A. Alireza, and S. Farhad. (2012). Correlation and path coefficient analysis for determining interrelationships among grain yield and related characters in corn hybrids ( $\mathrm{Zea}$ mays L). Intl. J. Agri. Crop Sci. 4(20), 1519-1522.

64. Zarei, B., D. Kahrizi, A. P. Aboughadaresh and F. Sadeghi. (2012). Correlation and path coefficient analysis for determining interrelationships among grain yield and related characters in corn hybrids. Intl. J. Agri. \& Crop Sci. (IJACS). 4 (20): 1519 152.

65. Oluwagbenga and Stephen. (2020). Correlation and Path Coefficient Analysis for Yield and Yield Components in Late Maturing Pro-vitamin A Synthetic Maize (Zea mays L.) Breeding Lines. American Journal of Experimental Agriculture. 42(1): 64-72

66. Wright, S. (1929). Path coefficients and path regressions: Alternative complementary concepts. Biometric, 16: 189-202.

67. Bhatt. (1973). Significance of path coefficient analysis in determining the nature of the trait. Euphytica. 22: 338-343.

68. Cramer, C.S., T.C. Wehner and S.B. Donagly. (1999). Path SAS: A SAS Computer program for path coefficient analysis of quantitative data. Journal of Heredity. 90(1): 260-262.

69. Dewey, D.R. and K.H. Lu. (1959). A correlation and Path-coefficient analysis of components of crested wheatgrass seed production. Agron. J., 51: 515-518.

70. Mohammadi, S. A., B. M. Prasanna and N. N. Singh. (2003). Sequential path model for determining interrelationships among grain yield and related traits in maize. Crop Sci., 43: 16901697.

71. Izge, Alabi SO, Maina YT. (2004). Correlation and path analysis of pod yield and yield components of groundnut (Arachis hypogaea L.). J. Sustain. Agric. Environ. 6(1): 15-21.

72. Asraur-Rehman, S. U. Saleem and G.M. Subhani. (2007). Correlation and path coefficient analysis in maize (Zea mays L). J.Agric Res., 45 (3) 177-183.

Cite This Article: Mamud Aman (2021). Genetic Variability, Heritability and Association of Quantitative Traits in Maize (Zea Mays L) Genotypes: Review Paper. EAS J Biotechnol Genet, 3(2), 38-46. 